\title{
ANALYSIS OF EPITOPE DISTRIBUTION OF ARABINOGALACTAN PROTEIN-EXTENSINS IN PEA (PISUM SATIVUM) NODULES OF WILD-TYPE AND MUTANTS IMPAIRED IN INFECTION THREAD GROWTH
}

\author{
(C) A.V. Tsyganova ${ }^{1}$, N. Brewin ${ }^{2}$, V.E. Tsyganov ${ }^{1,3}$ \\ ${ }^{1}$ All-Russia Research Institute for Agricultural Microbiology, Saint Petersburg, Russia; \\ ${ }^{2}$ John Innes Centre, Norwich, United Kingdom; \\ ${ }^{3}$ Saint Petersburg Scientific Center of RAS, Saint Petersburg, Russia \\ Cite this article as: Tsyganova AV, Brewin N, Tsyganov VE. \\ Analysis of epitope distribution of arabinogalactan protein-extensins in pea (Pisum sativum) nodules of wild-type and mutants \\ impaired in infection thread growth. Ecological genetics. 2019;17(3):5-12. https://doi.org/10.17816/ecogen 1735 - 12.
}

Received: 08.05.2019

Revised: 26.06 .2019

Accepted: 23.09 .2019

Background. Arabinogalactan protein-extensins (AGPE) play an important role at several stages of legumeRhizobium symbiosis, including root colonization and development of infection structures, particularly infection threads. The focus of this study is the involvement of AGPEs in the progress of tissue and cell colonization by Rhizobium. Materials and methods. Immunogold electron microscopy with monoclonal antibodies MAC204 and MAC236 was used to analyse the distribution and abundance of epitopes of AGPE in wild-type and symbiotically defective pea mutants. Results. In the nodules of the wild-type line SGE, both AGPE epitopes were detected to the same extent in the matrix of infection threads and infection droplets. In the nodules of the mutant line SGEFix ${ }^{-} 1$ (sym40), the level of labelling by MAC204 was significantly higher than with SGE in both infection threads and infection droplets, but the level of labelling by MAC236 was only increased in the infection droplets. In the mutant line SGEFix ${ }^{-}-2($ sym $33-3)$, a relatively high level of both epitopes was observed among all analysed genotypes. The double mutant line RBT3 (sym33-3, sym40) showed an intermediate level of labelling for both epitopes in infection threads compared with the parental mutants. In SGEFix ${ }^{-}$-1, an abnormal distribution of both epitopes was observed in the intercellular space matrix. The MAC204 epitope was found in the cell walls of SGEFix ${ }^{-}-1$ and in the infection thread walls of SGEFix ${ }^{-}-2$, whereas in RBT3 this epitope was detected in both types of walls. Conclusions. The sym33-3 and sym40 mutations have different effects on the accumulation of AGPE epitopes recognised by MAC204 and MAC236. This indicates that both the Sym33 and the Sym40 genes affect the composition of AGPE in the matrix of infection threads and infection droplets.

Keywords: legume-Rhizobium symbiosis; plant-microbe interface; infection thread; symbiotic mutants; gene interaction; AGP-Extensin glycoproteins; monoclonal antibodies.

\section{INTRODUCTION}

Colonization of plant cells of legumes with rhizobial cells is accompanied by a progressive remodelling of the plant-microbial interface, leading to symbiotic nitrogen fixation within root nodules. In response to a rhizobial infection, the host cells apparently modify the structure and composition of the cell wall and extracellular matrix [1, 2]. In legumes, a key component of the plant extracellular matrix is arabinogalactan protein-extensin (AGPE) - a family of hydroxyproline-rich proteins characterised by alternating extensin and arabinogalac$\tan$ motifs [3]. For the immunolocalisation of AGPE, monoclonal antibody MAC265 has been widely used, recognising a glycoprotein with a molecular mass in the region of $95 \mathrm{kDa}[4-8]$. Immunolocalisation with MAC265 clearly shows that AGPEs are secreted into the lumen of the infection threads in all legumes that have been examined [1].
The physical and biochemical properties of AGPE glycoproteins suggest that they may have a significant impact on the process of colonization of host tissues and cells by rhizobia. AGPE molecules apparently combine the biophysical properties of soluble gums (characteristic of AGPs) with the more structural and defensive properties of extensins (which generally serve to harden plant cell walls in response to pathogen attack or mechanical stress). Because of the very high content of tyrosine residues, it has been proposed that AGPE macromolecules may become cross-linked and insolubilized under oxidative and peroxide-rich conditions. This cross-linking might serve to regulate the growth of the infection thread itself as a result of a progressive fluid-to-solid transition in the embedding matrix of AGPE $[1,7,9,10]$.

Because of the structural complexity of AGPEs, it has been difficult to analyse their function directly by forward or reverse genetics. On the other hand, previous studies 
using MAC265 antibody, have indicated some heterogeneity of AGPE distribution in mutants impaired in infection thread development [8]. To gain more information about the involvement of AGPE in infection structures, we used monoclonal antibodies MAC204 and MAC236 to study the distribution of additional epitopes associated with AGPEs during the infection of pea nodules in the wildtype line SGE; in two mutant lines, SGEFix--1 (sym40) and SGEFix ${ }^{-}-2$ (sym33-3); and in the double mutant line RBT3 (sym33-3, sym40).

\section{MATERIALS AND METHODS}

\section{Plant material and bacterial strain}

Pea (Pisum sativum L.) mutant lines, forming ineffective nodules and the wild-type line SGE were used in this study (Table 1). Plants were inoculated with Rhizobium leguminosarum bv. viciae strain 3841 [18].

Growth conditions and sampling of material for analysis

Plants were raised in a growth chamber VB1514 (Vötch, Germany) (day: night $-16: 8 \mathrm{~h}$; temperature $21^{\circ} \mathrm{C}$; relative humidity $75 \%$; illumination $490 \mathrm{mLm} \cdot \mathrm{m}^{-2} \cdot \mathrm{s}^{-1}$ ). Seeds were surface-sterilised by treatment for $30 \mathrm{~min}$ with concentrated sulfuric acid at room temperature, washed with sterile distilled water, and inoculated at the time of planting ( $1 \mathrm{ml}$ of aqueous suspension contained $10^{8}-10^{9}$ bacteria). Sterile vermiculite moistened with a nutrient solution without nitrogen [19] was used as a substrate. Nodules (10 plants per variant) were harvested at 14 days after inoculation.

\section{Monoclonal antibodies}

For immunoelectron microscopy, antibodies MAC204 [4] and MAC236 [5], which recognise the AGPE matrix of infection threads were used. These were obtained from the collection of the John Innes Centre, Norwich, United Kingdom.

\section{Sample preparation}

Nodules were harvested from roots, transferred in $2.5 \%$ glutaraldehyde (Sigma-Aldrich, USA) in $0.5 \mathrm{M}$ cacodylate buffer ( $\mathrm{pH}$ 7.2). Nodules were given a glancing cut on one side to improve penetration of the fixative. After vacuum infiltration, floating nodules were discarded, and the fixative was replaced with a fresh solution. After $16 \mathrm{~h}$ of fixation at room temperature, the nodules were dehydrated in a graded series of increasing concentrations of ethanol at $-35^{\circ} \mathrm{C}$, infiltrated and polymerized in London Resin White acrylic resin (Sigma-Aldrich, St. Louis, MO, USA) using benzoin methyl ether as a catalyst for UV polymerization at $-20^{\circ} \mathrm{C}$.

\section{Immunogold analysis}

For immunogold electron microscopy, ultrathin sections $(90-100 \mathrm{~nm})$ were obtained on a Leica EM UC7 ultramicrotome (Leica Microsystems, Vienna, Austria) and collected on gold grids coated with $4 \%$ pyroxylin and carbon. After blocking in $50 \mathrm{mM}$ glycine in PBS $\left(2.48 \mathrm{~g} / 1 \mathrm{NaH}_{2} \mathrm{PO}_{4}\right.$, $\left.21.36 \mathrm{~g} / 1 \mathrm{Na}_{2} \mathrm{HPO}_{4}, 87.66 \mathrm{~g} / 1 \mathrm{NaCl}, \mathrm{pH} 7.4\right)$ for $15 \mathrm{~min}$ and in $\mathrm{ABB}$ blocking buffer $(5 \% \mathrm{BSA}, 0.1 \%$ cold water fish gelatin (CWFS), 5-10\% normal goat serum, $15 \mathrm{mM}$ $\mathrm{NaN}_{3}$ in PBS, pH 7.4) (Aurion, Wageningen, The Netherlands) for $30 \mathrm{~min}$, grids were washed several times in $0.1 \%$ acetylated BSA (BSA-C) (Aurion, Wageningen, The Netherlands) in PBS and incubated with primary antibodies diluted $1: 50$ in $0.1 \%$ BSA-C overnight at $4{ }^{\circ} \mathrm{C}$. After washing in $0.1 \% \mathrm{BSA}-\mathrm{C}$, the sections were incubated with secondary antibodies, goat anti-rat IgG conjugated to colloidal gold (particle size $10 \mathrm{~nm}$; Amersham International, Emirsch, UK), diluted $1: 50$ in $0.1 \%$ BSA-C for $4 \mathrm{~h}$ at room temperature. After washing in PBS for $20 \mathrm{~min}$ and then in deionized water for $30 \mathrm{~min}$, sections were counterstained in $2 \%$ uranyl acetate for $1 \mathrm{~h}$, followed by lead citrate for $1 \mathrm{~min}$. Sections were examined and photographed using a JEM-1400 transmission electron microscope (JEOL Corp., Tokyo, Japan) at $80 \mathrm{kV}$.

\section{Negative controls}

To conduct the specificity of the immunogold labelling procedures several negative controls were undertaken. Negative controls were treated with either a non-specific secondary antibody (goat anti-mouse IgG) or a gold-conjugated secondary antibody (goat anti-rat IgG) without primary antibody. No specific label was observed on the sections

Table 1

Plant material used in the study

\begin{tabular}{|l|l|c|}
\hline \multicolumn{1}{|c|}{ Genotype } & \multicolumn{1}{|c|}{ Phenotype } & References \\
\hline SGE & Wild-type & {$[11,12]$} \\
\hline SGEFix $^{-}-1(\text { sym40 })^{*}$ & Hypertrophied infection droplets and infection threads, abnormal bacteroids & {$[12-14]$} \\
\hline SGEFix $^{-}-2($ sym33-3)** & Abnormal infection thread growth inside nodule, no bacterial release*** & {$[12-14]$} \\
\hline RBT3 $($ sym33-3, sym40) & Abnormal infection thread growth inside nodule, no bacterial release & {$[15]$} \\
\hline
\end{tabular}

Note: * the Sym40 gene of P. sativum is orthologous to the M. truncatula EFD gene [16]. ** The Sym33 gene is orthologous to the M. truncatula IPD3 gene [17]. *** The mutant line SGEFix -2 (sym33-3) has leaky phenotype and in some cells or some nodules bacterial release occurs $[12,14]$. 
when processing with a non-specific secondary antibody (data not shown) and when using gold-conjugated secondary antibody without the primary antibody (data not shown).

\section{Quantitative analysis of immunogold labelling}

At least five different samples of nodules and at least 30 profiles of infection threads were examined for immunolocalisation with MAC204 or MAC236. The areas of infection thread (for all investigated pea lines) or infection droplet (for the wild-type line SGE and mutant line SGEFix ${ }^{-}-1$ (sym40)) sections were evaluated and the number of gold particles per unit area was calculated. The areas and the number of gold particles were measured using software Zen 2 Core version 2.5 (Carl Zeiss, Jena, Germany). The data were presented as the number of gold particle $/ \mu \mathrm{m}^{2}$. They were analysed by one-way ANOVA using the software SigmaPlot for Windows version 12.5
(Systat Software, Inc, San Jose, California, USA). Means were compared by the Dunn's test $(p<0.05)$.

\section{RESULTS}

In the nodules of the wild-type SGE line, immunolabelling with MAC204 and MAC236 was observed in infection threads (Fig. 1, $a, d$ ) and infection droplets (Fig. 1, b,e). Both AGPE epitopes were detected in the same quantities in the infection structures of wild-type nodules, but their abundance was slightly higher in infection droplets (Table 2). Along the edges of some infection threads and droplets, the labelling was more intense, both with MAC204 and with MAC236, suggesting that this may represent the region where newly synthesized matrix was deposited (Fig. 1, $c, f$ ). In symbiosomes and the walls of infection threads, labelling by MAC204 and MAC236 was not detected in wild-type tissues (data not shown).

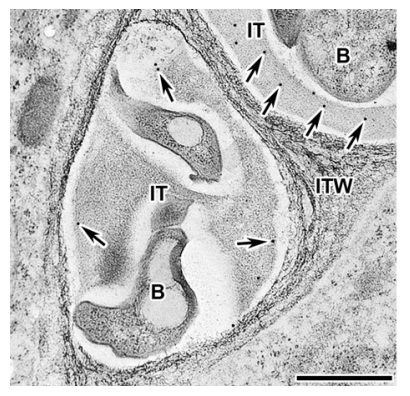

$a$

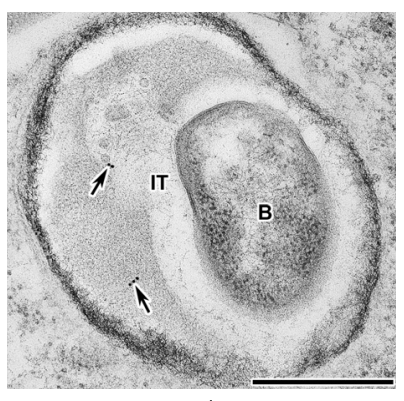

$d$

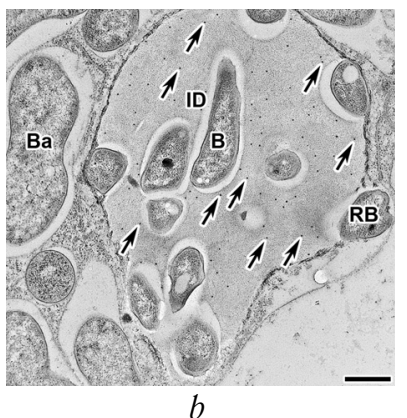

$b$

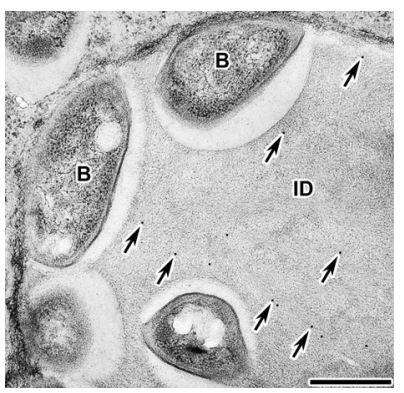

$e$
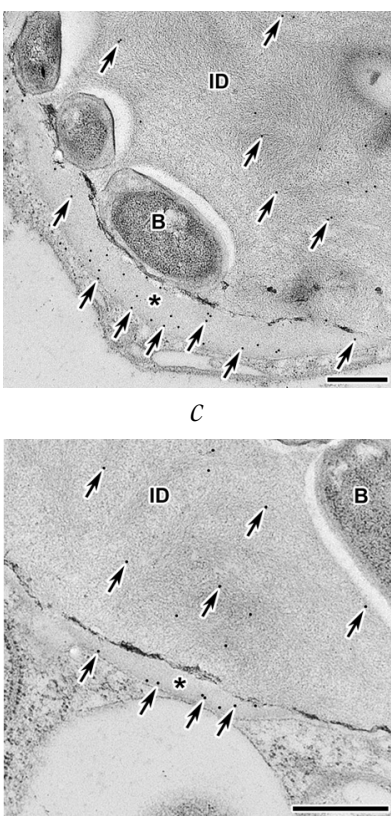

$f$

Fig. 1. Immunogold labelling showing the distribution of arabinogalactan protein-extensin epitopes in thin sections from the nodules of pea wild-type SGE: $a-c-$ MAC204; $d-f-$ MAC236. IT - infection thread, ITW - infection thread wall, ID - infection droplet, $\mathrm{B}$ - bacterium, RB - releasing bacterium, Ba - bacteroid, * - newly synthesised matrix; arrows indicate gold particles. Bar: $500 \mathrm{~nm}$

Table 2

Distribution of arabinogalactan protein-extensin epitopes labelled with monoclonal antibodies MAC204 and MAC236 in infection structures in the nodules of pea wild-type and mutant lines at 14 days after inoculation

\begin{tabular}{|l|c|c|c|c|}
\hline \multirow{2}{*}{ Genotype } & \multicolumn{2}{c|}{ Infection threads } & \multicolumn{2}{c|}{ Infection droplets } \\
\cline { 2 - 5 } & MAC204 & MAC236 & MAC204 & MAC236 \\
\hline SGE & $5.10 \pm 0.34^{\mathrm{b}}$ & $5.57 \pm 0.25^{\mathrm{ab}}$ & $8.52 \pm 1.16^{\mathrm{c}}$ & $7.20 \pm 0.55^{\mathrm{c}}$ \\
\hline SGEFix -1 (sym40) & $14.38 \pm 0.45^{\mathrm{d}}$ & $4.78 \pm 0.13^{\mathrm{a}}$ & $24.42 \pm 1.08$ & $13.03 \pm 0.91^{\mathrm{d}}$ \\
\hline SGEFix -2 (sym33-3) & $28.05 \pm 0.92$ & $22.09 \pm 0.95$ & nd & nd \\
\hline RBT3 (sym33-3, sym40) & $20.65 \pm 0.73$ & $9.18 \pm 0.52$ & nd & nd \\
\hline
\end{tabular}

Note: Results are presented as the number of gold particles $/ \mu \mathrm{m}^{2}$. Mean value $\pm \operatorname{SEM}(n=20-25)$ are shown. Means denoted by the same letters within a column $\left({ }^{\mathrm{a}}\right)$ and within a row $\left({ }^{\mathrm{b}-\mathrm{d}}\right)$ are not significantly different at $p<0.05$ based on Dunn's test; nd, not detectable. 


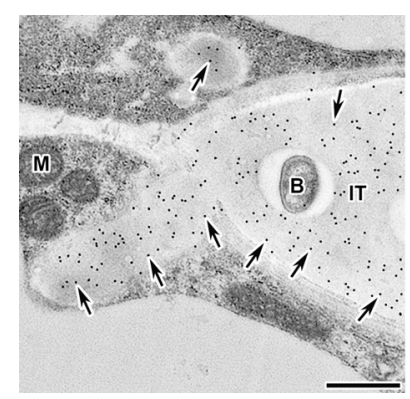

$a$
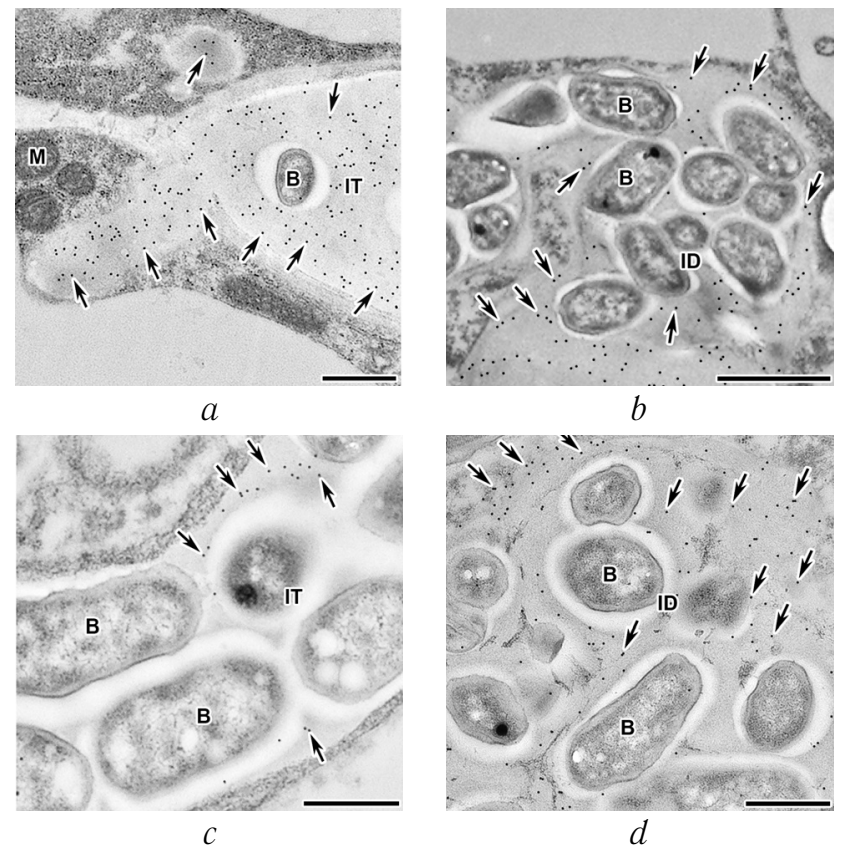

Fig. 2. Distribution of arabinogalactan protein-extensin epitopes in the nodules of pea mutant line SGEFix ${ }^{-}-1$ (sym40): $a, b-$ MAC204; $c, d-$ MAC236. IT - infection thread, ID - infection droplet, B - bacterium, $M-$ mitochondrion; arrows indicate gold particles. Bar: $a, b=1 \mu \mathrm{m}$, $c, d=500 \mathrm{~nm}$

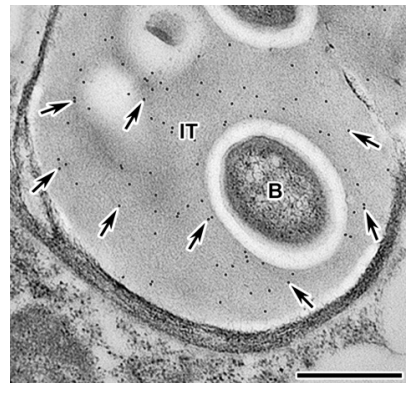

$a$

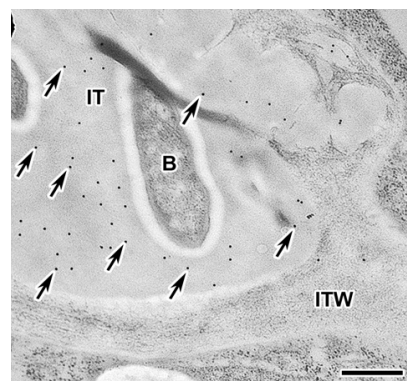

C

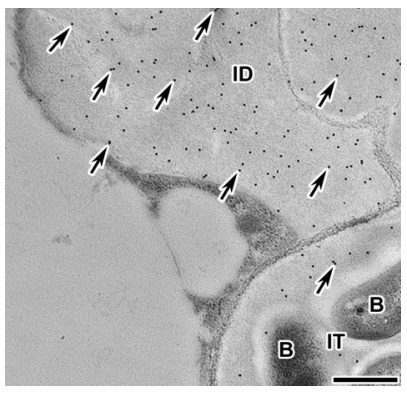

$b$

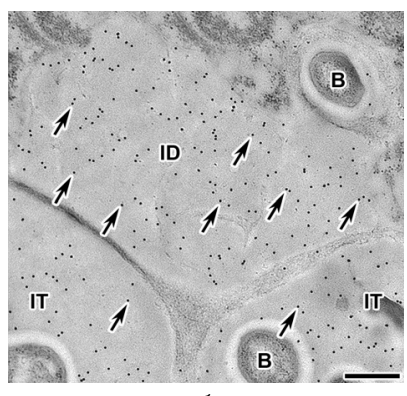

$d$
Fig. 4. Distribution of arabinogalactan protein-extensin epitopes in the nodules of pea mutant line SGEFix ${ }^{-}-2$ (sym33-3): $a, b-$ MAC204; $c, d-$ MAC236. IT - infection thread, ITW - infection thread wall, ID - infection droplet, B - bacterium; arrows indicate gold particles. Bar: 500 nm.

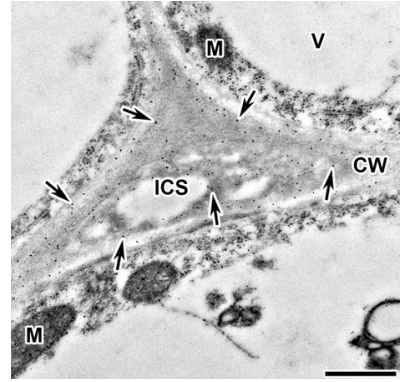

$a$
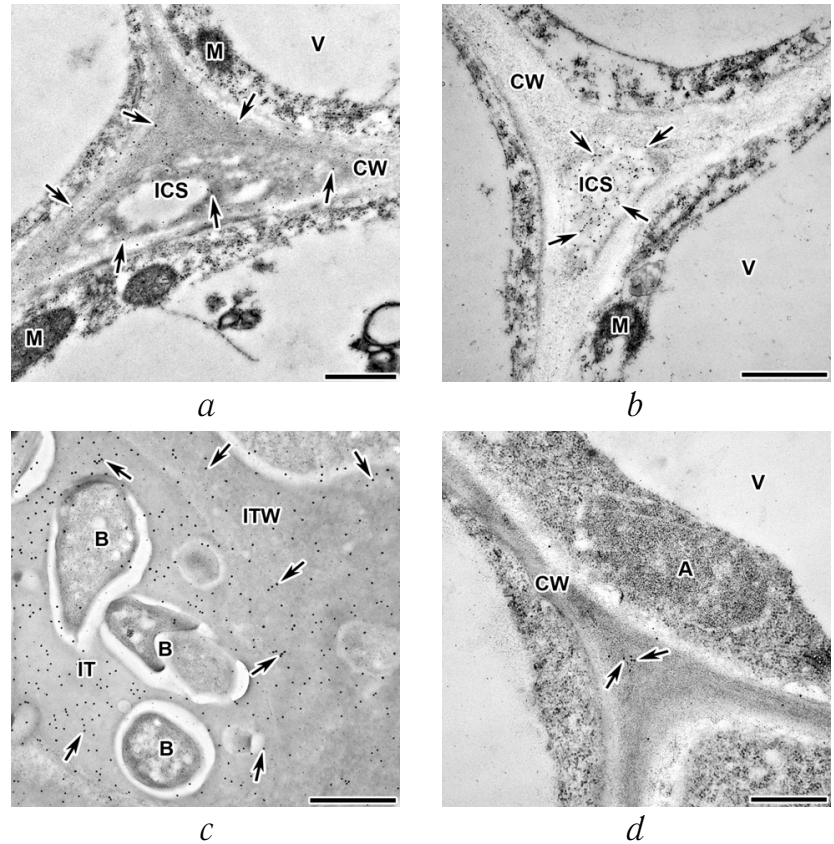

Fig. 3. Distribution of arabinogalactan protein-extensin epitopes in cell walls in the nodules of pea mutant lines SGEFix ${ }^{-}-1$ $(\operatorname{sym} 40)(a, b)$ and SGEFix $-2(\operatorname{sym} 33-3)(c, d): a, c, d-$ MAC204, $b$ - MAC236. V - vacuole, $M$ - mitochondrion, A - amyloplast, CW - cell wall, ICS - intercellular space, IT - infection thread, ITW - infection thread wall, B - bacterium; arrows indicate gold particles. Bar: 500 nm

In the mutant line $\mathrm{SGEFix}^{-}-1$ (sym40), the material of the matrix of infection threads and infection droplets was labelled with MAC204 (Fig. 2, $a, b$ ) and with MAC236 (Fig. 2, $c, d$ ). At the same time, the extent of AGPE epitope labelling by MAC204 was significantly higher than in the wild-type line in both infection threads and infection droplets (Table 2). By contrast, the extent of AGPE epitope labelling by MAC236 was only increased in infection droplets (Table 2). In addition, in the mutant line SGEFix $^{-}-1$ (sym40), the epitope recognised by MAC204 was present in the cell walls and the extracellular matrix of the expanded intercellular spaces specific for this mutant line (Fig. 3, a), while the epitope recognised by MAC236 was observed only in the matrix of the intercellular spaces (Fig. 3, b).

When nodule samples from the mutant line $\mathrm{SGEFix}^{-}-2$ (sym33-3) were examined, it was found that there was specific and abundant labelling with antibodies MAC204 (Fig. 4, $a, b$ ) and MAC236 (Fig. 4, c, d) both in the matrix of "locked" infection threads where bacteria release did not occur (Fig. 4, $a, c$ ) and in infection droplets devoid of bacteria (Fig. 4, b, d). Quantitative analysis revealed that these samples yielded the maximum level of labelling for both epitopes among all genotypes analysed ( see Table 2). (In this mutant, infection droplets were observed only rarely, and these were not considered in the 


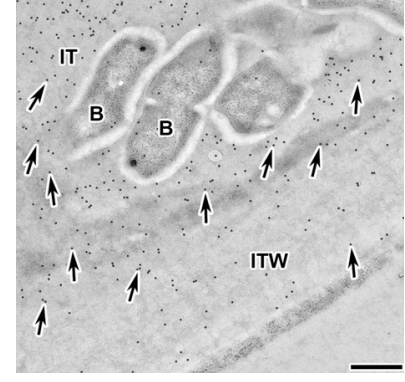

$a$

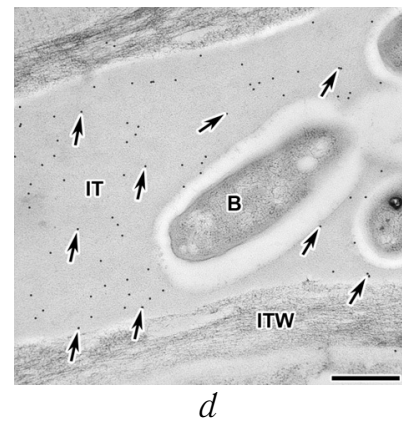

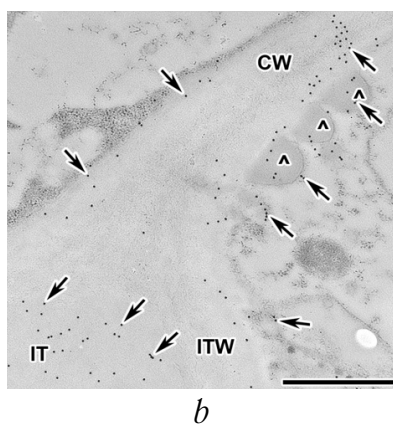

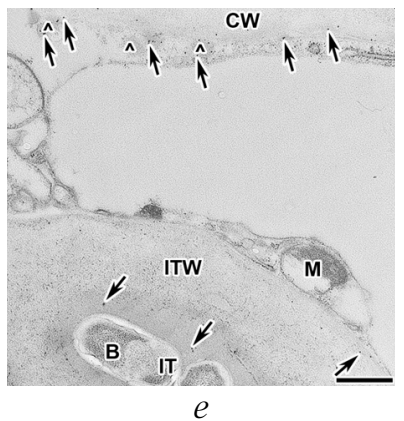

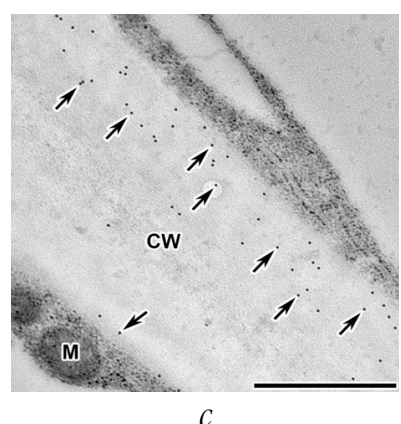

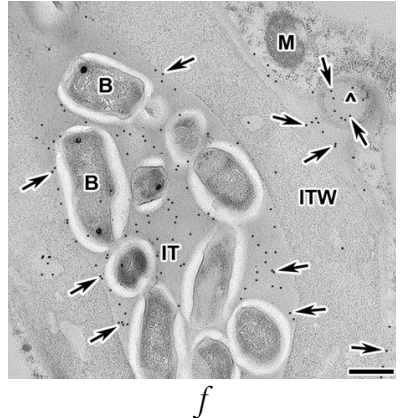

Fig. 5. Distribution of arabinogalactan protein-extensin epitopes in the nodules of pea double mutant line RBT3 (sym33-3, sym40): $a-c-$ MAC204; $d-f-$ MAC236. IT - infection thread, B - bacterium, ITW - infection thread wall, CW - cell wall, $\mathrm{M}$ - mitochondrion, ${ }^{\wedge}$ - transport vesicles with intercellular matrix; arrows indicate gold particles. Bar: $500 \mathrm{~nm}$

quantitative analysis.) The epitope recognised by MAC204 was also found as a component of the walls of infection threads (Fig. 3,c). Furthermore, in the cell walls, the MAC204-epitope was represented by a small number of gold particles (Fig. 3, d). By contrast the epitope recognised by MAC236 was not detected in the cell walls and infection thread walls in this mutant line (data not shown).

In the double mutant line RBT3 (sym33-3, sym40), both AGPE epitopes were detected in the matrix of "locked" infection threads (Fig. 5, $a, d$ ). Quantitative analysis revealed an intermediate level of both epitopes in infection threads compared with the parental mutant lines SGEFix ${ }^{-}-2$ (sym33-3) and SGEFix ${ }^{-}-1$ (sym40) (Table 2). Moreover, the MAC204 label was observed in the infection thread wall (Fig. 5,a), in the cell wall (Fig. 5, c) and in the vesicles transporting the material of extracellular matrix to the cell walls (Fig. 5, $b, e$ ) and the walls of the infection thread (Fig. 5, f).

\section{DISCUSSION}

We have previously studied the distribution of AGPE, recognised by monoclonal antibody MAC265, in the nodules of the wild-type line SGE and in the ineffective mutants SGEFix ${ }^{-}-1$ (sym40) and SGEFix -2 (sym33-3) and also in double mutants carrying the sym33-3 allele [8]. This study revealed strong labelling of MAC265 epitope in the matrix of infection threads and infection droplets. In the present study, it was shown that labelling with MAC204 and with MAC236 was increased in samples from SGEFix ${ }^{-}-1$ (sym40) in comparison with the wild-type line: both antibodies labelled more intensively in infection droplets (Fig. 2, $b, d$ ) while MAC204, but not MAC236, yielded relatively strong labelling in infection threads (Fig. 2, a). Among all genotypes analysed, the mutant line SGEFix ${ }^{-}-2$ (sym33-3) showed the strongest labelling of both epitopes in infection threads (Table 2). Previously, some heterogeneity in labelling of MAC265 was detected in mutants carrying the sym $33-3$ allele; it was present in the matrix of some, but not all, infection threads [8]. In the double mutant RBT3 (sym33-3, sym40), the amount of label of both epitopes was intermediate between the parental mutant genotypes SGEFix ${ }^{-}-1$ $($ sym 40$)$ and SGEFix ${ }^{-}-2$ (sym33-3). This indicates the complementation of sym 33-3 and sym 40 mutations in relation to the accumulation of the AGPE epitopes detected by antibodies MAC204 and MAC236 in the matrix of infection threads. Thus, although the sym33-3 mutation is epistatic over the sym40 mutation with respect to the structural organization of nodules [15], the Sym33 and Sym40 genes can apparently participate in independent pathways involved in the formation of glycoprotein components of the matrix of infection threads and infection droplets.

In a previous study using MAC265 antibody, we found evidence for mis-targeting of AGPE secretion into the lumen of the infection thread in the mutant line SGEFix $^{-}-1$ (sym40). This led to the accumulation of a large amount of MAC265 epitope in the intercellular space and was apparently accompanied by a change in the direction of secretion of the vesicles from infection thread 
walls to the cell wall [8]. In the present study, a similar abnormal secretion was detected in relation to the epitope recognised by MAC236 (Fig. 3, c), whereas the secretion of the epitope recognised by MAC204 occurred not only in the intercellular space matrix, but also into the cell wall (Fig. 3, a). Furthermore, in the double mutant line RBT3 (sym33-3, sym40), there was evidence for directional secretion of vesicles carrying the MAC204 and MAC236 epitopes to the cell walls and infection thread walls (Fig. 5, b, e, f). Previously, in the nodules of this mutant line, vesicles transporting the MAC265-epitope to the cell walls were observed [8]. Moreover, in the double mutant line RBT3 (sym33-3, sym40), MAC204 label was identified in the cell walls and infection thread walls (Fig. 5, a, c), as well as in the infection thread walls of the mutant line SGEFix ${ }^{-}-2$ (sym33-3) (Fig. 3, c) and in the cell walls of the mutant line SGEFix ${ }^{-}-1$ (sym40) (Fig. 3,a). These results provide further confirmation that the sym33-3 and sym40 mutations interact by complementation type with respect to the accumulation of AGPE epitopes recognised by MAC204 and MAC236.

In this study, both epitopes were present in equal amounts in infection threads and infection droplets in the nodules of the wild-type line SGE. At the same time, in the mutant line SGEFix ${ }^{-}-1$ (sym40) and the double mutant line RBT3 (sym33-3, sym40), the epitope recognised by MAC204 was more abundant than the epitope recognised by MAC236 (Table 2). It may indicate that a mutation in the Sym40 gene leads to the accumulation of AGPEs with slightly different epitopes.

The precise mode of AGPE functioning in the growth and development of infection structures, particularly infection threads, is unknown since these glycoproteins have a complex structure. It also needs to be investigated whether all AGPE proteins, or specific sequences are responsible for biological activity [1, 2]. We carried out comparative analysis of the distribution of the $95 \mathrm{kDa}$ molecular weight AGPE with the help of monoclonal antibodies reacting with different epitopes of this macromolecule [8]. In the present and previous studies [8] using nodules of mutant pea lines with impaired development of infection structures, it has been demonstrated that there is variation in the abundance of three different epitopes associated with AGPE in the matrix of infection threads and infection droplets, suggesting that specific sequences of AGPE macromolecule can play a role in the development of symbiotic nodules.

\section{Acknowledgments}

This work was supported by Russian Science Foundation (grant number 16-16-10035).

\section{REFERENCES}

1. Brewin NJ. Plant cell wall remodelling in the Rhizobium-legume symbiosis. Crit Rev Plant Sci. 2004;23(4): 293-316. https://doi.org/10.1080/07352680490480734.
2. Nguema-Ona E, Vicré-Gibouin M, Cannesan M-A, Driouich A. Arabinogalactan proteins in root-microbe interactions. Trends Plant Sci. 2013;18(8):440-449. https://doi.org/10.1016/j.tplants.2013.03.006.

3. Showalter AM, Basu D. Extensin and arabinogalactan-protein biosynthesis: glycosyltransferases, research challenges, and biosensors. Front Plant Sci. 2016;7:814. https://doi.org/10.3389/ fpls.2016.00814.

4. Bradley DJ, Wood EA, Larkins AP, et al. Isolation of monoclonal antibodies reacting with peribacteroid membranes and other components of pea root nodules containing Rhizobium leguminosarum. Planta. 1988;173(2): 149-160. https://doi.org/10.1007/bf00403006.

5. VandenBosch KA, Bradley DJ, Knox JP, et al. Common components of the infection thread matrix and the intercellular space identified by immunocytochemical analysis of pea nodules and uninfected roots. EMBO J. 1989;8(2):335-341. https://doi. org/10.1002/j.1460-2075.1989.tb03382.x.

6. Rae AL, Bonfante-Fasolo P, Brewin NJ. Structure and growth of infection threads in the legume symbiosis with Rhizobium leguminosarum. Plant J. 1992;2(3):385-395. https://doi.org/10.1111/j.1365313X.1992.00385.x.

7. Rathbun EA, Naldrett MJ, Brewin NJ. Identification of a family of extensin-like glycoproteins in the lumen of Rhizobium-induced infection threads in pea root nodules. Mol Plant Microbe Interact. 2002;15(4): 350-359. https://doi.org/10.1094/MPMI.2002.15.4.350.

8. Tsyganova AV, Tsyganov VE, Findlay KC, et al. Distribution of legume arabinogalactan protein-exten$\sin$ (AGPE) glycoproteins in symbiotically defective pea mutants with abnormal infection threads. Cell Tissue Biol. 2009;3( 1):93-102. https://doi.org/10.1134/ S1990519X09010131.

9. Reguera M, Abreu I, Brewin NJ, et al. Borate promotes the formation of a complex between legume AGP-extensin and rhamnogalacturonan II and enhances production of Rhizobium capsular polysaccharide during infection thread development in Pisum sativum symbiotic root nodules. Plant Cell Environ. 2010;33(12):2112-2120. https://doi.org/10.1111/ j. 1365-3040.2010.02209.x.

10. Gucciardo S, Rathbun EA, Shanks $M$, et al. Epitope tagging of legume root nodule extensin modifies protein structure and crosslinking in cell walls of transformed tobacco leaves. Mol Plant Microbe Interact. 2005;18(1): 24-32. https://doi.org/10.1094/MPMI-18-0024.

11. Kosterin OE, Rozov SM. Mapping of the new mutation $b l b$ and the problem of integrity of linkage group I [Internet]. 1993. Available from: https://www. researchgate.net/publication/312428570_Mapping_ of_the_new_mutation_blb_and_the_problem_of_integrity_of_linkage_group_I. 
12. Tsyganov VE, Morzhina EV, Stefanov SY, et al. The pea (Pisum sativum L.) genes sym33 and sym40 control infection thread formation and root nodule function. Mol Gen Genet. 1998;259(5):491-503. https://doi.org/10.1007/s004380050840.

13. Tsyganov VE, Borisov AY, Rozov SM, Tikhonovich IA. New symbiotic mutants of pea obtained after mutagenesis of laboratory line SGE. Pisum Genet. 1994;26:36-37.

14. Voroshilova VA, Boesten B, Tsyganov VE, et al. Effect of mutations in Pisum sativum L. genes blocking different stages of nodule development on the expression of late symbiotic genes in Rhizobium leguminosarum bv. viciae. Mol Plant-Microbe Interact. 2001;14(4):471-476. https://doi. org/10.1094/MPMI.2001.14.4.471.

15. Tsyganov VE, Seliverstova EV, Voroshilova VA, et al. Double mutant analysis of sequential functioning of pea (Pisum sativum L.) genes Sym13, Sym33, and Sym40 during symbiotic nodule development. Ecol Genet. 2010;8(2):3-8. https://doi.org/10.17816/ecogen823-8.
16. Nemankin TA. Analysis of pea (Pisum sativum L.) genetic system, controlling development of arbuscular mycorrhiza and nitrogen-fixing symbiosis. [dissertation] Saint Petersburg; 2011. 18 p. (In Russ.). Available from: http://earthpapers.net/analiz-geneticheskoysistemy-goroha-pisum-sativum-1-kontroliruyuscheyrazvitie-arbuskulyarnoy-mikorizy-i-azotfiksiruyusch.

17. Ovchinnikova E, Journet E-P, Chabaud M, et al. IPD3 controls the formation of nitrogen-fixing symbiosomes in pea and Medicago spp. Mol Plant-Microbe Interact. 2011;24(11):1333-1344. https://doi. org/10.1094/MPMI-01-11-0013.

18. Wang TL, Wood EA, Brewin NJ. Growth regulators, Rhizobium and nodulation in peas. Planta. 1982;155(4):350-355. https://doi.org/10.1007/ BF00429464.

19. Borisov AY, Rozov SM, Tsyganov VE, et al. Sequential functioning of Sym13 and Sym31, two genes affecting symbiosome development in root nodules of pea (Pisum sativum L.). Mol Gen Genet. 1997;254(5):592 -598. https://doi.org/10.1007/ s004380050456.

\title{
АНАЛИЗ РАСПРЕДЕЛЕНИЯ ЭПИТОПОВ АРАБИНОГАЛАКТАНПРОТЕИНОВ-ЭКСТЕНЗИНОВ В КЛУБЕНЬКАХ ГОРОХА (PISUM SATIVUM) ДИКОГО ТИПА И МУТАНТОВ С НАРУШЕНИЯМИ РОСТА ИНФЕКЦИОННОЙ НИТИ
}

\author{
(C) А.В. Цыганова ${ }^{1}$, Н. Бревин ${ }^{2}$, В.Е. Цыганов ${ }^{1,3}$ \\ ${ }^{1}$ ФГБНУ «Всероссийский научно-исследовательский институт сельскохозяйственной микробиологии», \\ Санкт-Петербург, Россия; \\ ${ }^{2}$ Центр Джона Иннеса, Норидж, Великобритания; \\ ${ }^{3}$ Санкт-Петербургский научный центр РАН, Санкт-Петербург, Россия
}

Для цитирования: Цыганова А.В., Бревин Н., Цыганов В.Е. Анализ распределения эпитопов арабиногалактанпротеинов-экстензинов в клубеньках гороха (Pisum sativum) дикого типа и мутантов с нарушениями роста инфекционной нити // Экологическая генетика. - 2019. - Т. 17. № 3. - C. 5-12. https://doi.org/10.17816/ecogen1735-12.

Арабиногалактанпротеин-экстензины (AGPE) играют важную роль на нескольких стадиях бобово-ризобиального симбиоза, включая колонизацию корней и развитие инфекционных структур, особенно инфекционных нитей. Основное внимание в этом исследовании уделено участию AGPE в последовательной колонизации тканей и клеток ризобиями. Для анализа распределения и количества эпитопов AGPE в клубеньках гороха дикого типа и неэффективных симбиотических мутантов была использована иммуноэлектронная микроскопия с моноклональными антителами MAC204 и MAC236. В клубеньках линии дикого типа SGE оба эпитопа AGPE были одинаково распределены в матриксе инфекционных нитей и инфекционных капель. В клубеньках мутантной линии SGEFix ${ }^{-} 1$ (sym40) количество метки MAC204 было значительно выше, чем у SGE, как в инфекционных нитях, так и в инфекционных каплях, но количество метки MAC236 было увеличено только в инфекционных каплях. У мутантной линии SGEFix ${ }^{-}-2$ (sym33-3) наблюдался самый высокий уровень обоих эпитопов среди всех анализируемых генотипов. У двойной мутантной линии RBT3 (sym33-3, sym40) зафиксирован промежуточный уровень накопления метки обоих эпитопов в инфекционных нитях по сравнению с родительскими мутантами. У SGEFix ${ }^{-}-1$ аномальное распределение обоих эпитопов наблюдалось в матриксе межклеточного пространства. Эпитоп МАС204 был обнаружен в клеточных стенках SGEFix ${ }^{-}-1$ и в стенках инфекционных нитей SGEFix ${ }^{-}$2, тогда как у RBT3 этот эпитоп был выявлен в обоих типах стенок. Мутации sym33-3 и sym40 по-разному влияют на накопление эпитопов AGPE, распознаваемых MAC204 и MAC236. Это указывает на то, что оба гена Sym33 и Sym40 влияют на состав AGPE в матриксе инфекционных нитей и инфекционных капель.

母лючевые слова: бобоворизобиальный симбиоз; растительно-микробный интерфейс; инфекционная нить; симбиотические мутанты; взаимодействие генов; AGPE-гликопротеины; моноклональные антитела. 
8. Информация об авторах

Анна Викторовна Цыганова - канд. биол. наук, ведущий научный сотрудник, лаборатория молекулярной и клеточной биологии. ФГБНУ «Всероссийский научно-исследовательский институт сельскохозяйственной микробиологии», Пушкин-8, Санкт-Петербург, Россия. SPIN: 9149-5662. E-mail: isaakij@mail.ru.

Николас Бревин - почетный профессор. Центр Джона Иннеса, Исследовательский парк Норвича, Норвич, Великобритания. E-mail: nick.brewin@jic.ac.uk.

Виктор Евгеньевич Цыганов - д-р биол. наук, заведующий лабораторией молекулярной и клеточной биологии, ФГБНУ «Всероссийский научно-исследовательский институт сельскохозяйственной микробиологии», Пушкин-8, Санкт-Петербург, Россия; старший научный сотрудник, Санкт-Петербургский научный центр РАН, Санкт-Петербург, Россия. SPIN: 6532-1332. E-mail: tsyganov@arriam.spb.ru.
(8) Authors and affiliations

Anna V. Tsyganova - Candidate of Biological Sciences, Leading Scientist, Laboratory of Molecular and Cellular Biology, Department of Biotechnology. All-Russia Research Institute for Agricultural Microbiology, Pushkin-8, St. Petersburg, Russia. SPIN: 9149-5662. E-mail: isaakij@mail.ru.

Nicholas J. Brewin - Professor, Emeritus Fellow, John Innes Centre, Norwich Research Park, Norwich, UK. E-mail: nick.brewin@ jic.ac.uk.

Viktor E. Tsyganov - Doctor of Biological Sciences, Head of the Laboratory, Laboratory of Molecular and Cellular Biology, Department of Biotechnology. All-Russia Research Institute for Agricultural Microbiology, Pushkin-8, St. Petersburg, Russia; Senior Scientist, Saint Petersburg Scientific Center RAS, St. Petersburg, Russia. SPIN: 6532-1332.E-mail: tsyganov@arriam.spb.ru. 